\title{
Influence of Seed Size and Ecological Factors on the Germination and Emergence of Field Bindweed (Convolvulus arvensis) ${ }^{1}$
}

\author{
Influência do Tamanho da Semente e Fatores Ecológicos na Germinação e na Emergência de \\ Convolvulus arvensis
}

TANVEER, A. ${ }^{2}$, TASNEEM, M. ${ }^{2}$, KHALIQ, A. ${ }^{2}$, JAVAID, M.M. ${ }^{3}$, and CHAUDHRY, M.N. ${ }^{4}$

\begin{abstract}
An understanding of seed germination ecology of weeds can assist in predicting their potential distribution and developing effective management strategies. Influence of environmental factors and seed size on germination and seedling emergence of Convolvulus arvensis (field bindweed) was studied in laboratory and greenhouse conditions. Germination occurred over a wide range of constant temperatures, between 15 and $40{ }^{\circ} \mathrm{C}$, with optimum germination between 20 and $25{ }^{\circ} \mathrm{C}$. Time to start germination, time to $50 \%$ germination and mean germination time increased while germination percentage and germination index decreased with an increase in temperature from $20{ }^{\circ} \mathrm{C}$, salinity and osmotic stress. However, germination was tolerant to low salt $(25 \mathrm{mM})$ or osmotic stress $(0.2 \mathrm{MPa})$, but as salinity and osmotic stress increased, germination percentage and germination index decreased. Seeds of $C$. arvensis placed at soil surface showed maximum emergence and decreased as seeding depth increased. Seeds of $C$. arvensis germinated over a wide range of $\mathrm{pH}$ (4 to 9) but optimum germination occurred at $\mathrm{pH} 6$ to 8. Under highly alkaline and acidic $\mathrm{pH}$, time to start germination, time to $50 \%$ germination and mean germination time increased while germination percentage and germination index decreased. Increase in field capacity caused decreased time to start germination, time to $50 \%$ germination and mean germination time but increased germination percentage and germination index. Bigger seeds had low time to start germination, time to $50 \%$ germination and mean germination time but high germination percentage and germination index. Smaller seeds were more sensitive to environmental factors as compared to larger or medium seeds. It can be concluded that except for $\mathrm{pH}$, all environmental factors and seed sizes adversely affect $C$. arvensis as regards seed germination or emergence and germination or emergence traits, and larger seeds result in improved stand establishment and faster germination than small seeds, regardless of moisture stress or deeper seeding depth.
\end{abstract}

Keywords: germination ecology, seed size, field bindweed, Convolvulus arvensis.

RESUMO - O entendimento sobre a ecologia de germinação de sementes de plantas daninhas pode ajudar a prever sua distribuição e a desenvolver estratégias eficazes de manejo. Fatores ambientais e tamanho da semente de Convolvulus arvensis foram estudados em laboratório e em casa de vegetação. A germinação ocorreu através de uma ampla gama de temperatura constante, de 15 a $40^{\circ} \mathrm{C}$, com a germinação ótima entre 20 e $25^{\circ} \mathrm{C}$. Otempo para iniciar a germinação e o tempo médio de germinação foram aumentados, enquanto a porcentagem e o índice de germinação foram reduzidos com o aumento da temperatura da salinidade e do estresse osmótico. Apesar de a germinação ter sido tolerante à baixa quantidade de sal (25 mM) ou estresse osmótico (-0,2 MPa), com o aumento da salinidade e do estresse osmótico, a porcentagem e o indice de germinação foram reduzidos. Sementes de C. arvensis colocadas na superficie do solo mostraram emergência máxima e diminuíram como aumento da profundidade de semeadura. Essas sementes germinaram em ampla gama de pH (4 a 9),

1 Recebido para publicação em 4.5.2012 e aprovado em 5.9.2012.

2 Department of Agronomy, University of Agriculture Faisalabad, 38040, Pakistan; ${ }^{3}$ Department of Agronomy, University College of Agriculture, University of Sargodha, 40100, Pakistan <mmansoorjavaid@gmail.com>; ${ }^{4}$ University College of Agriculture and Environmental Sciences, The Islamia University of Bahawalpur, Pakistan.

Planta Daninha, Viçosa-MG, v. 31, n. 1, p. 39-51, 2013 
porém a germinação ótima ocorreu em pH 6 a 8. Sob pH altamente alcalino e ácido, o tempo para iniciar a germinação e o tempo médio de germinação foram aumentados, ao passo que a porcentagem e o indice de germinação foram reduzidos. O aumento na capacidade de campo acelerou a germinação. Sementes maiores aumentaram a porcentagem e o indice de germinação. Sementes menores foram mais sensiveis aos fatores ambientais, em relação às de tamanho maior ou médio. Pode-se concluir que todos os fatores ambientais e o tamanho das sementes influenciaram a germinação das sementes de C. arvensis, ou a emergência e a germinação. Conclui-se também que sementes maiores resultaram em melhor estabelecimento do estande e germinação mais rápida em relação às sementes pequenas, independentemente do estresse de umidade ou da semeadura mais profunda.

Palavras-chave: ecologia da germinação, tamanho da semente, corriola/trepadeira, Convolvulus arvensis.

\section{INTRODUCTION}

Convolvulus arvensis is one of the world's top noxious weeds and it is found in 32 different crops in 54 countries (Holm et al., 1991). Convolvulus arvensis is native to Europe and Asia, and it grows in temperate, tropical, and Mediterranean climates (Lyons, 1998; Gubanov et al., 2004). It belongs to the Convolvulaceae family with 40 or more genera and about 1,200 species. Represented in Pakistan by 13 native and cultivated genera, C. arvensis is a major problem in wheat, cotton, sugarcane, potato, and other crops (Memon \& Asma, 2004).

Seed germination and emergence is one of the most critical phases in plant development at which the weed can compete for an ecological niche (Forcella et al., 2000) and is mediated by various environmental variables such as temperature, salt stress, light, $\mathrm{pH}$, seed burial depth and soil moisture (Chachalis \& Reddy, 2000; Koger et al., 2004; Chauhan, et al., 2006). Temperature and light are considered the most important environment signals regulating germination, species distribution and ecological interaction (Chauhan \& Jhonson, 2008). Salt stress has an important bearing on plant germination and growth and varies from species to species. Salinity may also cause toxic effects of sodium and chloride ions on the germinating seed and may affect seed germination by preventing uptake of water due to low external osmotic potential (Khajeh - Hosseini et al., 2003). The impact of soil moisture on germination varies among weed species, and field conditions may differ spatially and temporally, depending on rainfall, temperature and soil type. Plant available water in the soil lies between field capacity $(-0.03 \mathrm{MPa})$ and permanent wilting point $(-1.5 \mathrm{MPa})$ (Miller \& Donahue, 2004), and it is assumed that water potential in wet, moist, semi arid and arid soils is 0,0 to $-0.03,-0.03$ to -0.75 and -0.75 to $-1.5 \mathrm{MPa}$, respectively. Effect of $\mathrm{pH}$ on weed seed germination is species dependent and some weeds germinate over a wider $\mathrm{pH}$ range (Zhou et al., 2005). Seed burial depth affects emergence (Koger et al., 2004) by influencing the availability of moisture, temperature and light exposure (Rao et al., 2008).

Variability in weed seed size may contribute to variability in seed germination, persistence, and emergence under different environmental factors (Bakker et al., 1998). The effects of seed size on germination and following seedling emergence have been investigated by many researchers in various crop species/cultivars (Willenborg et al., 2005). However, results varied widely across species. With increased seed size, higher germination and emergence were determined in oat (Willenborg et al., 2005). Information about the effects of these factors provides a biological basis for the spread and establishment of weeds. Such knowledge is also useful in modeling the invasion potential of weed species (Kriticos et al., 2003) and can improve the ability to control weeds. To date, no research has been especially conducted on germination ecology of $C$. arvensis with different seed sizes. The objective of this study is to determine the effects of temperature, salt and osmotic stress, field capacity, $\mathrm{pH}$ and burial depth on germination, seedling emergence and other germination or emergence traits of seeds of C. arvensis of different sizes. 


\section{MATERIAL AND METHODS}

\section{Seed description and germination tests}

Mature seeds of $C$. arvensis were harvested in late April and early May of 2009 from the Agronomic Research Farm $\left(31^{\circ} \mathrm{N}\right.$ and $\left.73{ }^{\circ} \mathrm{E}\right)$, University of Agriculture, Faisalabad, Pakistan. The seeds were dried at room temperature $\left(20-25^{\circ} \mathrm{C}\right)$ for 30 days and then stored in paper bags at room temperature until use in the experiments. Seeds were graded manually (based on visual observation) into large, medium and small sizes. The weight of 100 seeds of the small, medium and large sized seeds was 480, 560 and $880 \mathrm{~g}$, respectively. The averaged seed size was $770 \times 1125,898 \times 1.440$ and $1.020 \times$ $1.820 \mathrm{~mm}$ of small, medium and large seeds, respectively.

Germination was determined by placing 25 seeds evenly on a $9 \mathrm{~cm}$ diameter Petri dish containing Whatman filter paper No. 10, moistened with $5 \mathrm{~mL}$ distilled water or a treatment solution. Seeds of $C$. arvensis were surface-sterilized by soaking in $10 \%$ sodium hypochlorite $(\mathrm{NaOCl})$ for five minutes, followed by five rinses with distilled water before the start of each germination trial. Except for seeding depth and field capacity experiments, seeds were placed between two sheets of moistened filter paper. All treatment solutions were applied at a rate of $5 \mathrm{~mL}$ and Petri dishes were wrapped with parafilm to reduce water loss. Germinated seeds whose radical was at least $2 \mathrm{~mm}$ long were counted and removed daily for a period of three weeks. In case of seeding depth and field capacity experiments, $15 \mathrm{~cm}$ diameter pots were used and $50 \mathrm{~mL}$ water per pot was initially applied in seeding depth experiments. Pots were left opened and watered as needed to maintained adequate soil moisture. A calculated amount of water was applied in field capacity experiments. Seedlings were considered emerged when a cotyledon was visible at the soil surface.

\section{Temperature}

Convolvulus arvensis seeds were moistened with distilled water and immediately placed in incubators separately at constant temperatures of $15,20,25,30,35,40$ and $45^{\circ} \mathrm{C}$. The experiment was maintained for two weeks and germination was assessed daily by opening the Petri dishes to count and remove the germinated seeds. The seeds were kept hydrated by adding distilled water as needed to avoid moisture effect.

\section{Salt stress and osmotic stress}

Seed germination as influenced by salt stress was evaluated using sodium chloride $(\mathrm{NaCl})$ solutions of $0,25,50,75,100,125,150$, $175,200,225$ and $250 \mathrm{mM}$. The average minimum and maximum temperatures recorded during the experiment were $17^{\circ} \mathrm{C}$ and $23{ }^{\circ} \mathrm{C}$. Convolvulus arvensis seeds were germinated in aqueous solution with osmotic potential of $0,-0.2,-0.4,-0.6$ and $-0.8 \mathrm{MPa}$. Osmotic potentials were prepared by respectively dissolving $0,91.6,129.5,183.1$ and $224.2 \mathrm{~g}$ polyethylene glycol 8000 in $1 \mathrm{~L}$ distilled water (Michel, 1983). The average minimum and maximum temperatures recorded during the experiment were $19{ }^{\circ} \mathrm{C}$ and $24{ }^{\circ} \mathrm{C}$.

\section{Filed capacity}

Emergence of $C$. arvensis was measured at three field capacity levels. Three soil samples of $100 \mathrm{~g}$ weight each were taken at the time of filling the plastic pots. These samples were then incubated at $105{ }^{\circ} \mathrm{C}$ for $24 \mathrm{~h}$. The oven dried samples were weighed and averaged to determine total moisture contents. After that, the saturation percentage of the three oven dried samples was approximated by measuring and then averaging the distilled water used to make completely saturated paste samples. Field capacity was determined by means of the following formula:

Field capacity $=$ Saturation percentage $/ 2$

Since the weight of each plastic pot plus filled soil and the moisture contents therein at the time of sowing were already known, the weight of each filled plastic pot containing moisture contents equal to $100 \%, 75 \%, 50 \%$ and $25 \%$ field capacity. Pots were placed in a greenhouse at an average day temperature of $22{ }^{\circ} \mathrm{C}$ and night temperature of $17^{\circ} \mathrm{C}$. 


\section{pH of buffer solutions}

Effect of $\mathrm{pH}$ on germination of $C$. arvensis was evaluated using buffer solutions of $\mathrm{pH} 4$ to 9 . Buffer solutions were prepared according to the method described by Chachalis \& Reddy (2000). A $2 \mathrm{mM}$ solution of MES [2-(N-morpholino) ethanesulfonic acid] was adjusted to $\mathrm{pH} 4, \mathrm{pH} 5$ and $\mathrm{pH} 6$ with $1 \mathrm{~N}$ sodium hydroxide $(\mathrm{NaOH})$. A 2 $\mathrm{mm}$ solution of HEPES [N-(2-hydroxymethyl) piperazine-N-(2-ethanesulfonic acid)] was adjusted to $\mathrm{pH} 7$ or 8 with $1 \mathrm{~N} \mathrm{NaOH}$. A pH 9 buffer was prepared with $2 \mathrm{~mm}$ TRICINE [N-Tris (hydroxymethyl) methylglycine] and adjusted with $1 \mathrm{~N} \mathrm{NaOH}$. Unbuffered deionized water was used in control. The average minimum and maximum temperatures were $18{ }^{\circ} \mathrm{C}$ and $23^{\circ} \mathrm{C}$, respectivelly during the experimental period.

\section{Seeding depth}

The effect of seed burial depth on seedling emergence was studied in a greenhouse. Ten seeds of the species were placed on the soil surface or covered with soil $(30 \%$ clay, $30 \%$ silt and $40 \%$ sand) to depth of 2, 4, 6 and $8 \mathrm{~cm}$ in $15 \mathrm{~cm}$ diameter plastic pots. Pots were left opened and watered as needed to maintain adequate soil moisture. Seedlings were considered emerged when a cotyledon was visible on the soil surface. Emergence was assessed for three weeks after sowing of seeds. The average minimum and maximum temperatures were $20^{\circ} \mathrm{C}$ and $25^{\circ} \mathrm{C}$ during the experiment period.

Time to obtain $50 \%$ germination or emergence $\left(T_{50}\right.$ or $\left.E_{50}\right)$ was calculated according to the following formula of Coolbear et al. (1984):

$$
T_{50} \text { or } E_{50}=t_{i}+\frac{\left(\frac{N}{2}-n_{i}\right)\left(t_{j}-t_{i}\right)}{\left(n_{j}-n_{i}\right)}
$$

where $N$ is the final number of germinated or emerged seeds and $n_{j}$ and $n_{i}$ are the cumulative number of seeds germinated by adjacent counts at times $t_{j}$ (day) and $t_{i}$, (day) respectively, when $n_{i}<\mathrm{N} / 2<n_{j}$. Mean germination or emergence time ( $M G T$ or $M E T$ ) was calculated according to the equation of Ellis \& Roberts (1981):

$$
M G T \text { or } M E T=\frac{\sum D n}{\sum n}
$$

where $n$ is the number of seeds that had germinated on day $D$ and $D$ is the number of days counted from the beginning of germination. The germination/emergence index ( $G I$ or $E I$ ) was calculated as described by the Association of Official Seed Analysis (AOSA, 1983) using the following formula:

$$
\begin{aligned}
G I \text { or } E I & =\frac{\text { Noof germinated } \text { or emerged seeds }}{\text { Days of first count }}+\ldots \\
& +\frac{\text { Noof germinated } \text { or emerged seeds }}{\text { Days of final t count }}
\end{aligned}
$$

\section{Statistical analysis}

All experiments were carried out in a completely randomized design in factorial arrangement with four replications. Data were subjected to analysis of variance (ANOVA) with the use of SAS (2002). The significant difference among treatment mean was identified by using Fisher, LSD at $\mathrm{P}<0.05$ (Steel et al., 1997). Nonlinear regression analysis was used to determine how $\mathrm{NaCl}$, osmotic stress, burial depth or field capacity affected percentage germination or emergence. Germination (\%) values at different concentrations of $\mathrm{NaCl}$ and osmotic potential were fitted to a functional three-parameter logistic model using Sigma Plot 2008 (version 11.0). The model fitted was $G(\%)=G_{\max } /[1+(x)$ $\left.\left.x_{50}\right)^{\text {Gara }}\right]$, where $G$ is the total germination (\%) at concentration $x, G_{\max }$ is the maximum germination (\%), $x_{50}$ is the $\mathrm{NaCl}$ concentration or osmotic potential for $50 \%$ inhibition of the maximum germination and $G_{\text {rate }}$ indicates the slope. A three-parameter logistic model $\{E(\%)$ $=E_{\max } /\left[1+\left(x / x_{50}\right)^{E}\right.$ rate $\left.]\right\}$ was fitted to $C$. arvensis for the seedling emergence $(\%)$ obtained at different burial depths $(0$ to $8 \mathrm{~cm})$ or different field capacity levels, where $E$ is the total seedling emergence (\%) or field capacity $x, E_{\max }$ is the maximum seedling emergence $(\%), x_{50}$ or field capacity for $50 \%$ inhibition of the maximum seedling emergence and $E_{\text {rate }}$ indicates the slope. 


\section{RESULTS AND DISCUSSION}

\section{Temperature}

Germination percentage and germination index decreased but time to start germination, time to $50 \%$ germination and mean germination time increased as seed size decreased (Figure 1 and Table 1). Seeds of $C$. arvensis germinated at temperatures from 15 to $40{ }^{\circ} \mathrm{C}$, while no germination was observed at $45^{\circ} \mathrm{C}$, the highest evaluated temperature. At temperature $20{ }^{\circ} \mathrm{C}$, time to start germination, time to $50 \%$ germination and mean germination were the lowest while germination percentage and germination index were the highest. Total germination averaged 58.33 and $48.33 \%$ at 20 and $25{ }^{\circ} \mathrm{C}$, respectively, with no statistical difference between these two temperatures. Convolvulus arvensis germination was $45 \%$ at $15{ }^{\circ} \mathrm{C}$ and $40 \%$ at $30{ }^{\circ} \mathrm{C}$ (Figure 1 ). A substantial reduction in germination percentage and germination index and an increase in time to start germination, time to $50 \%$ germination and mean germination time were observed below $20^{\circ} \mathrm{C}$ and above $30^{\circ} \mathrm{C}$. The optimum germination temperature of C. arvensis lies between $20^{\circ} \mathrm{C}$ and $25^{\circ} \mathrm{C}$, which was similar to the optimum germination temperature range of other members of the Convolvulacae family such as pitted morning glory (Ipomoea lacunose) (Oliveira \& Norsworth
2006) and bigroot morning glory (Ipomea pandurata) (Horak \& Wax, 1991). Thus, germination of $C$. arvensis can occur over a wide range of temperatures, supporting the extended period of emergence observed in the field throughout the year in Pakistan.

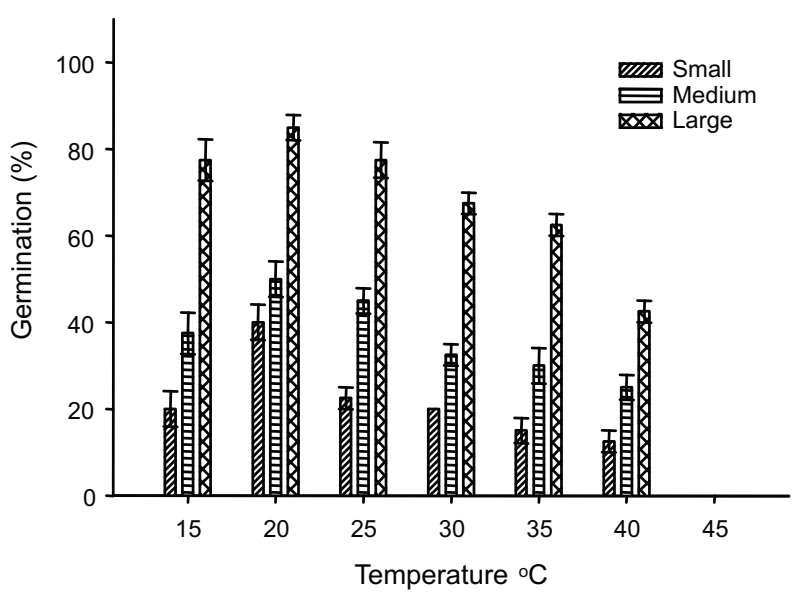

Figure 1 - Effect of seed size and temperature on germination percentage of C. arvensis. Vertical bars represent \pm standard error of the mean.

\section{Salt stress}

A three-parameter logistic model was fitted to the germination $(\%)$ of three seed sizes of C. arvensis obtained at different $\mathrm{NaCl}$ concentrations (Figure 2). Germination of

Table 1 - Effect of seed size and temperature on different germination parameters of C. arvensis

\begin{tabular}{|c|c|c|c|c|}
\hline Treatment & $\begin{array}{c}\text { Time to start } \\
\text { germination (days) }\end{array}$ & $\begin{array}{c}\text { Time to } 50 \% \\
\text { germination (days) }\end{array}$ & $\begin{array}{l}\text { Mean germination } \\
\text { time (days) }\end{array}$ & $\begin{array}{c}\text { Germination } \\
\text { index }\end{array}$ \\
\hline \multicolumn{5}{|l|}{ Seed size } \\
\hline Large & $0.85 \mathrm{~b}^{*}$ & $0.69 \mathrm{~b}$ & 1.45 & $7.73 \mathrm{a}$ \\
\hline Medium & $1.17 \mathrm{a}$ & $1.03 \mathrm{a}$ & 1.57 & $3.08 \mathrm{~b}$ \\
\hline Small & $1.25 \mathrm{a}$ & $1.12 \mathrm{a}$ & 1.65 & $1.51 \mathrm{c}$ \\
\hline $\operatorname{LSD}(0.05)$ & 0.172 & 0.211 & $\mathrm{NS}$ & 0.930 \\
\hline \multicolumn{5}{|l|}{ Temperature $\left({ }^{\circ} \mathrm{C}\right)$} \\
\hline 15 & $1.16 \mathrm{bc}$ & $0.99 \mathrm{c}$ & $1.77 \mathrm{bc}$ & $5.39 \mathrm{bc}$ \\
\hline 20 & $1.00 \mathrm{c}$ & $0.61 \mathrm{~d}$ & $1.17 \mathrm{~d}$ & $7.15 \mathrm{a}$ \\
\hline 25 & $1.08 \mathrm{c}$ & $0.93 \mathrm{~cd}$ & $1.61 \mathrm{c}$ & $6.18 \mathrm{ab}$ \\
\hline 30 & $1.41 \mathrm{ab}$ & $1.17 \mathrm{bc}$ & $1.82 \mathrm{bc}$ & $3.98 \mathrm{~cd}$ \\
\hline 35 & $1.41 \mathrm{ab}$ & $1.35 \mathrm{~b}$ & $2.13 \mathrm{ab}$ & $3.62 \mathrm{de}$ \\
\hline 40 & $1.58 \mathrm{a}$ & $1.60 \mathrm{a}$ & $2.43 \mathrm{a}$ & $2.43 \mathrm{a}$ \\
\hline 45 & $\mathrm{NG}$ & NG & $\mathrm{NG}$ & NG \\
\hline $\operatorname{LSD}(0.05)$ & 0.262 & 0.322 & 0.435 & 1.421 \\
\hline
\end{tabular}

* The values followed by different letters are significantly different at $P<0.05$. NS $=$ Non significant and NG= No Germination. 
C. arvensis seeds followed an exponential response to increasing seed size and salt concentration with decreased germination as salt concentration increased from 25 to $250 \mathrm{mM}$

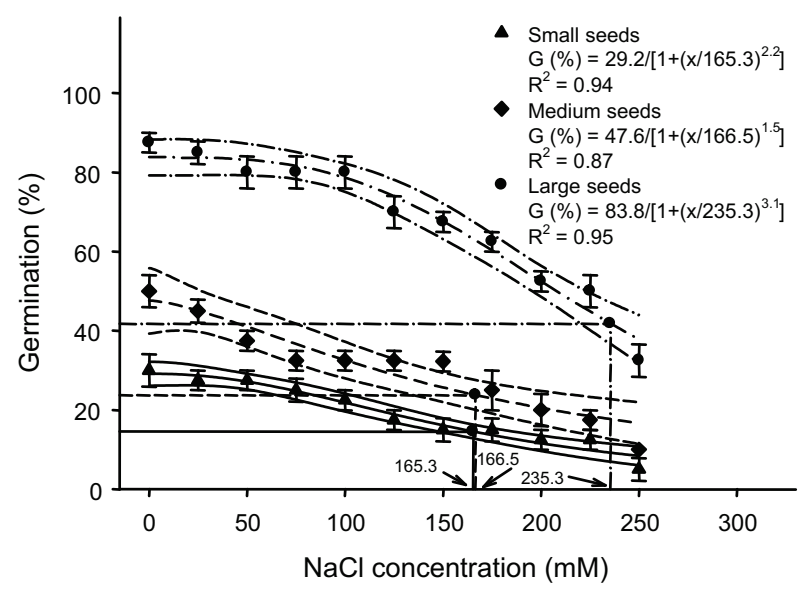

Figure 2 - Effect of seed size and $\mathrm{NaCl}$ concentration (mM) on seed germination of $C$. arvensis. Solid lines represent a threeparameter logistic model fitted to the germination data for C. arvensis and thin lines represent $95 \%$ confidence interval. Continuous lines (-) represent small sized seeds, dash lines $(---)$ represent medium sized seeds and dash lines with a dot between dash $(-\cdot-\cdot-)$ represent large sized seeds. Vertical bars represent \pm standard error of the mean if greater than the symbol size and decreased in seed size from large to small (Figure 2). Small seeds have not germinated more than $30 \%$ even in the control treatment with distilled water. The fitted model showed that $50 \%$ of the maximum germination of C. arvensis occurred at the $\mathrm{NaCl}$ concentration of $165.3 \mathrm{mM}$. Maximum germination in medium seeds was $50 \%$ at control and decreased up to $10 \%$ at highest concentration level $(250 \mathrm{mM})$. The fitted model showed that medium sized $C$. arvensis seeds had $50 \%$ germination of the maximumat the $\mathrm{NaCl}$ concentration of $166.5 \mathrm{mM}$ (Figure 2). Large sized seeds had maximum germination and were fairly tolerant to different $\mathrm{NaCl}$ concentraton levels when compared with small or medium sized seeds (Figure 2). The model fitted to large sized seeds showed that $50 \%$ germination of the maximum occurred at the $\mathrm{NaCl}$ concentration of $235.3 \mathrm{mM}$. Time to start germination, time to $50 \%$ germination and mean germination time were high for smaller seeds of $C$. arvensis but such seeds had low germination percentage and germination index in contrast to medium sized and large seeds. Germination index at the salt concentration of $25 \mathrm{mM}$ was 3.73, which was reduced to 0.46 at the salt concentration of $250 \mathrm{mM}$ (Table 2). In

Table 2 - Effect of seed size and salinity on different germination parameters of C. arvensis

\begin{tabular}{|c|c|c|c|c|}
\hline Treatment & $\begin{array}{c}\text { Time to start } \\
\text { germination (days) }\end{array}$ & $\begin{array}{c}\text { Time to } 50 \% \\
\text { germination (days) }\end{array}$ & $\begin{array}{l}\text { Mean germination } \\
\text { time (days) }\end{array}$ & $\begin{array}{c}\text { Germination } \\
\text { index }\end{array}$ \\
\hline \multicolumn{5}{|l|}{ Seed size } \\
\hline Large & $2.45 \mathrm{~b}^{*}$ & $2.45 \mathrm{~b}$ & 3.40 & $5.09 \mathrm{a}$ \\
\hline Medium & $2.56 \mathrm{~b}$ & $2.75 \mathrm{a}$ & 3.57 & $1.74 \mathrm{~b}$ \\
\hline Small & $3.10 \mathrm{a}$ & $2.99 \mathrm{a}$ & 3.83 & $0.90 \mathrm{c}$ \\
\hline $\operatorname{LSD}(0.05)$ & 0.266 & 0.273 & $\mathrm{NS}$ & 0.452 \\
\hline \multicolumn{5}{|l|}{$\mathrm{NaCl}$ concentration $(\mathrm{mM})$} \\
\hline Control (distilled water) & $2.00 \mathrm{e}$ & $1.92 \mathrm{~d}$ & $2.73 \mathrm{~d}$ & $4.32 \mathrm{a}$ \\
\hline 25 & $2.00 \mathrm{e}$ & $1.95 \mathrm{~d}$ & $2.86 \mathrm{~d}$ & $3.73 \mathrm{ab}$ \\
\hline 50 & $2.08 \mathrm{de}$ & $2.01 \mathrm{~d}$ & $2.96 \mathrm{~d}$ & $3.45 \mathrm{bc}$ \\
\hline 75 & $2.08 \mathrm{de}$ & $2.09 \mathrm{~cd}$ & $3.09 \mathrm{~cd}$ & $3.15 \mathrm{bcd}$ \\
\hline 100 & 2.16 cde & $2.16 \mathrm{~cd}$ & $3.16 \mathrm{~cd}$ & $3.13 \mathrm{bcd}$ \\
\hline 125 & $2.50 \mathrm{cde}$ & $2.32 \mathrm{~cd}$ & $3.24 \mathrm{~cd}$ & $2.71 \mathrm{~cd}$ \\
\hline 150 & 2.50 cde & $2.56 \mathrm{c}$ & $3.46 \mathrm{~cd}$ & $2.63 \mathrm{~cd}$ \\
\hline 175 & $2.58 \mathrm{~cd}$ & $3.22 \mathrm{~b}$ & $3.60 \mathrm{bcd}$ & $2.44 \mathrm{~d}$ \\
\hline 200 & $3.00 \mathrm{c}$ & $3.40 \mathrm{~b}$ & $4.07 \mathrm{bc}$ & $1.37 \mathrm{e}$ \\
\hline 225 & $3.58 \mathrm{~b}$ & $3.63 \mathrm{~b}$ & $4.48 \mathrm{~b}$ & $0.95 \mathrm{ef}$ \\
\hline 250 & $5.25 \mathrm{a}$ & $4.95 \mathrm{a}$ & $5.89 \mathrm{a}$ & $0.46 \mathrm{f}$ \\
\hline $\operatorname{LSD}(0.05)$ & 0.510 & 0.511 & 1.072 & 0.866 \\
\hline
\end{tabular}

* The values followed by different letters are significantly different at $P<0.05$. NS $=$ Non significant. 
contrast, other germination parameters such as time to start germination, time to $50 \%$ germination and mean germination time increased with increased salt concentration and decreased seed size. Germination of turnipweed (Rapistrum rugosum) decreased with increased salinity level (Chauhan et al., 2006) similarly to the results of the present study. These data suggested that even at high salinity, a proportion of field bindweed seed may germinate, especially bold seeds. This could account for the success in field conditions with high salinity level. The ability of bold seeds to germinate at high salinity level enables this weed to spread in plain areas of Pakistan. This could be an important attribute of such weed that enables it to colonize saline areas. Similarly to $C$. arvensis, seeds of giant sensitive plant (Mimosa invisa) (Chauhan \& Johnson, 2008d) and african mustard (Brassica tournefortii; Chauhan et al., 2006c) germinated at a high concentration of $\mathrm{NaCl}$. Decrease in germination might result from the increase in the intake of toxic ions at high $\mathrm{NaCl}$ concentration. Koyro and Eisa (2008) reported that salt stress caused cessation of metabolism or inhibition of certain steps in metabolic sequences of germination. Similarly, Smith \& Comb (1991) reported that salt stress increased the intake of toxic ions, which may have altered certain enzymatic or hormonal activities of the seeds during germination.

\section{Osmotic stress}

Regarding seed size or osmotic potential, large sized seeds had high germination percentage at varying osmotic potentials as compared to other seed sizes (Figure 3). Germination of small sized seeds decreased from 40 to $7 \%$ as osmotic potential decreased from 0 to $-0.8 \mathrm{MPa}$. According to the threeparameter logistic model, the osmotic potential for $50 \%$ inhibition of the maximum germination of $C$. arvensis was $-0.4 \mathrm{MPa}$. Medium sized seeds have maximum germination (54\%) at control (distilled water) and decreased up to $10 \%$ as osmotic potential decreased to $-0.8 \mathrm{MPa}$, and the model showed that $50 \%$ inhibition of the maximum germination occurred at $-0.53 \mathrm{MPa}$ (Figure 3). The model showed that large sized seeds had maximum germination $(83.8 \%)$ at control and decreased to $12 \%$ at highest osmotic stress $(-0.8 \mathrm{MPa})$ and $50 \%$ inhibition of the maximum germination occurred at $-0.59 \mathrm{MPa}$. Medium and large sized seeds tolerated osmotic stress up to $-0.2 \mathrm{MPa}$ and showed similar germination to $0 \mathrm{MPa}$ whereas germination steadily decreased in small sized seeds with increased osmotic stress (Figure 2). Time to start germination, time to $50 \%$ germination and mean germination time were not affected by seed size while germination index was lower in small sized seeds as compared to medium or large sized seeds (Table 3). Germination index also decreased from 3.90 to 0.32 as osmotic potential decreased from 0 to $-0.8 \mathrm{MPa}$. There was a difference of 0.83 days in time to start germination under control and at -0.8 MPa osmotic potential, which indicated that high osmotic stress caused delay in germination. Time to $50 \%$ germination was increased by 0.97 days from 0 to $-0.8 \mathrm{MPa}$. Under non-stress conditions, mean germination time was 2.72 days and it increased to 3.75 days at $-0.8 \mathrm{MPa}$ osmotic potential (Table 3). These results indicated that water stress is the most important factor limiting seed germination and inhibiting germination and vigor traits of C. arvensis. These results help to explain the

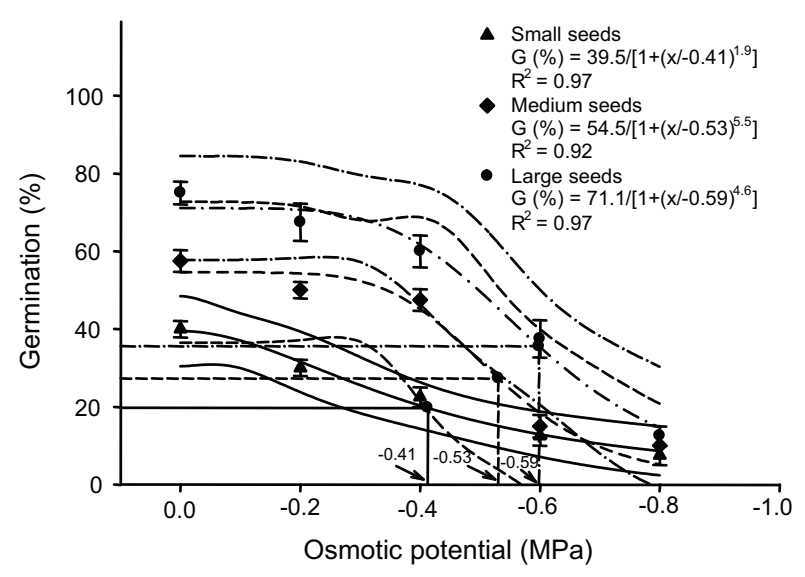

Figure 3 - Effect of seed size and osmotic potential (MPa) on seed germination of $C$. arvensis. Solid lines represent a threeparameter logistic model fitted to the germination data for C. arvensis and thin lines represent $95 \%$ confidence interval. Continuous lines (-) represent small sized seeds, dash lines $(---)$ represent medium sized seeds and dash lines with a dot between dash $(-\cdot-\cdot-)$ represent large sized seeds. Vertical bars represent \pm standard error of the mean if greater than the symbol size. 
Table 3 - Effect of seed size and osmotic stress on different germination parameters of C. arvensis

\begin{tabular}{|c|c|c|c|c|}
\hline Treatment & $\begin{array}{c}\text { Time to start } \\
\text { germination (days) }\end{array}$ & $\begin{array}{c}\text { Time to } 50 \% \\
\text { germination (days) }\end{array}$ & $\begin{array}{l}\text { Mean germination } \\
\text { time (days) }\end{array}$ & $\begin{array}{c}\text { Germination } \\
\text { index }\end{array}$ \\
\hline \multicolumn{5}{|l|}{ Seed size } \\
\hline Large & 2.10 & 2.23 & 3.08 & $3.35 \mathrm{a}^{*}$ \\
\hline Medium & 2.25 & 2.40 & 3.20 & $2.29 \mathrm{~b}$ \\
\hline Small & 2.50 & 2.56 & 3.33 & $1.50 \mathrm{c}$ \\
\hline $\operatorname{LSD}(0.05)$ & NS & $\mathrm{NS}$ & NS & 0.427 \\
\hline \multicolumn{5}{|l|}{ Osmotic potential (MPa) } \\
\hline Control (distilled water) & $2.00 \mathrm{~b}$ & $2.00 \mathrm{~b}$ & $2.72 \mathrm{~b}$ & $3.90 \mathrm{a}$ \\
\hline-0.2 & $2.00 \mathrm{~b}$ & $2.20 \mathrm{~b}$ & $2.87 \mathrm{~b}$ & $3.44 \mathrm{ab}$ \\
\hline-0.4 & $2.00 \mathrm{~b}$ & $2.32 \mathrm{~b}$ & $3.27 \mathrm{ab}$ & $3.14 \mathrm{~b}$ \\
\hline-0.6 & $2.58 \mathrm{ab}$ & $2.50 \mathrm{ab}$ & $3.42 \mathrm{ab}$ & $1.10 \mathrm{c}$ \\
\hline-0.8 & $2.83 \mathrm{a}$ & $2.97 \mathrm{a}$ & $3.75 \mathrm{a}$ & $0.32 \mathrm{~d}$ \\
\hline $\operatorname{LSD}(0.05)$ & 0.651 & 0.617 & 0.728 & 0.552 \\
\hline
\end{tabular}

* The values followed by different letters are significantly different at $\mathrm{P}<0.05$. NS $=$ Non significant.

association between rain or water availability and germination of $C$. arvensis. Our finding also showed that germination trait of $C$. arvensis was inhibited with increased osmotic stress, which may result in the production of ailing seedlings. However, larger seeds have more than $50 \%$ germination even at $-0.4 \mathrm{MPa}$. Several weed species such as crafton weed (Eupatorium adenophoum); (Lu et al., 2006), taxsasweed (Caperonia palustris) (Koger et al., 2004); syndrella (Syndrella nodiflora) (Chauhan \& Johnson, 2009b); annual sowthistle (Sonchus oleraceus) (Chauhan \& Johnson, 2006a); goose grass (Eleusine indica), (Chauhan and Johnson, 2008a) and goat weed (Scoparia dulcis) (Jain \& Singh 1989) are sensitive to osmotic stress. In contrast, other weed species such as venice mallow (Hibiscus trionum) (Chachalis et al., 2008c); turnipweed (Rapistrum rugosum) (Chauhan et al., 2006b) and hairy nightshade (Solanum sarrachoides) (Zhou et al., 2005) were shown to be likely to tolerate low water potential. Other researchers hypothesized that increased seed size enables seedling emergence under low soil moisture because larger seeds produce longer radicles that can access deeper water resources, contain relatively more nutritional reserves, and have decreased metabolic rates (Leishman et al., 2000).

\section{Field capacity}

Decrease in field capacity significantly reduced germination percentage in all sizes of C. arvensis seeds (Figure 4). At high field capacity, germination percentage was higher as compared to lower levels. Emergence percentage was $22 \%$ at $25 \%$ field capacity level which increased to $40.83 \%$ at $100 \%$ field capacity (Figure 4). However, large sized seeds showed considerable germination (35\%) even at lowest field capacity (25\%). A threeparameter logistic model was fitted to emergence data of small, medium and large

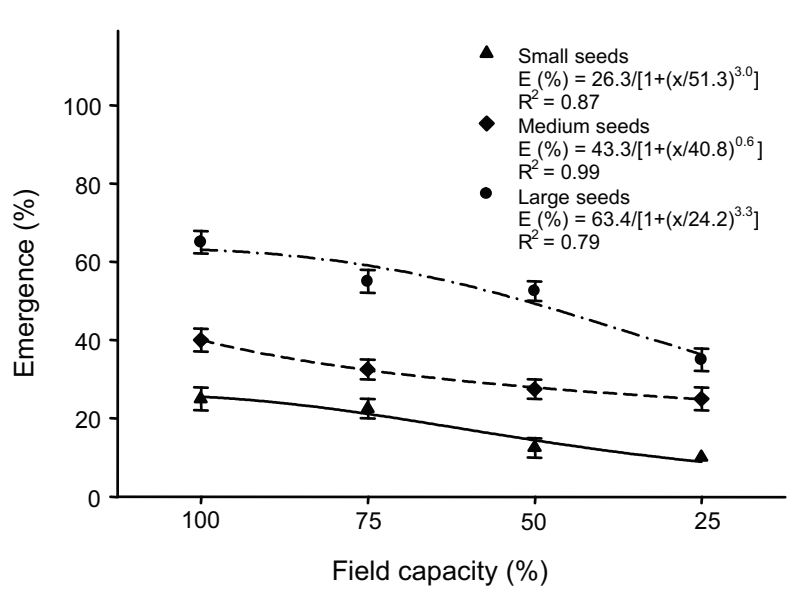

Figure 4 - Effect of seed size and field capacity (\%) on seed emergence of $C$. arvensis. Solid lines represent a threeparameter logistic model fitted to the germination data for C. arvensis. Continuous lines (-) represent small sized seeds, dash lines (- - ) represent medium sized seeds and dash lines with a dot between dash $(-\cdot-\cdot-)$ represent large sized seeds. Vertical bars represent \pm standard error of the mean if greater than the symbol size. 
sized seeds of $C$. arvensis (Figure 4). According to the model, field capacity for $50 \%$ inhibition of the maximum emergence was $51.3,40.8$ and $24.2 \%$ for small, medium and large sized seeds, respectively. For smaller seeds of C. arvensis, time to start emergence was high but emergence index was low in contrast to medium and large seeds (Table 4). Time to start emergence was 6.33 days at $100 \%$ field capacity level, and it increased to 8 days at $25 \%$ field capacity level (Table 4 ). Fifty percent of the population of $C$. arvensis seeds was germinated in 6.02 days at $100 \%$ level which increased to 7.95 days at $25 \%$ field capacity level (Table 4). Similar results were observed by Hussain et al. (2003) with minimum emergence of Amaranthus viridis at 25\% field capacity and by Laubhan \& Shaffer (2006) with maximum emergence of Cirsium arvense and Lepidium latifolium at $100 \%$ field capacity. These results are further supported by Aboyami \& Adeyini (2005), who observed that emergence was less and time to start emergence was higher under $25 \%$ field capacity. Leishman et al. (2000) reported that larger seeds of the same species enable emergence under low moisture content.

\section{pH of buffered solution}

Germination of $C$. arvensis was affected significantly by $\mathrm{pH}$ of buffer solution as well as by seed size. Larger seeds had greater potential to germinate under all $\mathrm{pH}$ levels as compared to medium and small seeds (Table 5 and Figure 5). The highest germination $(47.50 \%)$ occurred at $\mathrm{pH} 7$ (Figure 5), which tended to decrease as $\mathrm{pH}$ moved to acidic or basic region. Maximum germination index (3.71) was observed at $\mathrm{pH} 7$ while it was minimum (1.53) at $\mathrm{pH} 9$ (Table 6). Time to start germination, time to $50 \%$ germination and mean germination time were 2.66 days, 2.52 days and 3.32 days at $\mathrm{pH} 9$, respectively; such times were reduced to 2.00 days, 1.63 days and 2.25 days at $\mathrm{pH} 7$ (Table 5). These results suggest that $C$. arvensis tends to germinate better in neutral and slightly acidic soils compared to alkaline soil environments. Optimum $\mathrm{pH}$ range for germination of C. arvensis seeds ranged between 6 and $8 \mathrm{~cm}$. This characteristic is common for invasive weed species (Susko et al., 1999; Watanabe et al., 2002) and it will aid the ability of C. arvensis to invade diverse habitats. Similar results were found by Oliveira $\&$ Norsworth (2006) in pitted morning glory (Ipomoea lacunosa). A number of previous studies indicated that the germination of weed species was not affected by $\mathrm{pH}$ levels from 4 to 9 (Thomas et al., 2006; Chachalis et al., 2008; Wang et al., 2009).

\section{Seeding depth}

Emergence of $C$. arvensis was affected significantly by seeding depth as well as by seed size. A three-parameter logistic model

Table 4 - Effect of seed size and field capacity on different parameter traits of C. arvensis

\begin{tabular}{|c|c|c|c|c|}
\hline Treatment & $\begin{array}{c}\text { Time to start } \\
\text { germination (days) }\end{array}$ & $\begin{array}{c}\text { Time to } 50 \% \\
\text { germination (days) }\end{array}$ & $\begin{array}{l}\text { Mean germination } \\
\text { time (days) }\end{array}$ & $\begin{array}{c}\text { Germination } \\
\text { index }\end{array}$ \\
\hline \multicolumn{5}{|l|}{ Seed size } \\
\hline Large & $6.31 \mathrm{~b}^{*}$ & 6.17 & 7.36 & $1.89 \mathrm{~A}$ \\
\hline Medium & $3.36 \mathrm{~b}$ & 6.41 & 7.60 & $0.88 \mathrm{~A}$ \\
\hline Small & $8.12 \mathrm{a}$ & 7.54 & 9.01 & $0.40 \mathrm{C}$ \\
\hline $\operatorname{LSD}(0.05)$ & 0.401 & NS & NS & 0.412 \\
\hline \multicolumn{5}{|l|}{ Field capacity (\%) } \\
\hline $25 \%$ & $8.00 \mathrm{a}$ & 7.95 & 8.89 & 0.67 \\
\hline $50 \%$ & $6.75 \mathrm{~b}$ & 6.62 & 7.98 & 0.91 \\
\hline $75 \%$ & $6.50 \mathrm{~b}$ & 6.23 & 7.70 & 1.28 \\
\hline $100 \%$ & $6.33 \mathrm{~b}$ & 6.02 & 7.54 & 1.38 \\
\hline $\operatorname{LSD}(0.05)$ & 0.463 & 1.642 & NS & NS \\
\hline
\end{tabular}


Table 5 - Effect of seed size and $\mathrm{pH}$ on different germination parameters of C. arvensis

\begin{tabular}{|c|c|c|c|c|}
\hline Treatment & $\begin{array}{c}\text { Time to start } \\
\text { germination (days) }\end{array}$ & $\begin{array}{c}\text { Time to } 50 \% \\
\text { germination (days) }\end{array}$ & $\begin{array}{l}\text { Mean germination } \\
\text { time (days) }\end{array}$ & $\begin{array}{c}\text { Germination } \\
\text { index }\end{array}$ \\
\hline \multicolumn{5}{|l|}{ Seed size } \\
\hline Large & $2.00 \mathrm{~b}^{*}$ & $1.71 \mathrm{~b}$ & $2.48 \mathrm{~b}$ & $4.63 \mathrm{a}$ \\
\hline Medium & $2.07 \mathrm{~b}$ & $1.83 \mathrm{~b}$ & $2.64 \mathrm{ab}$ & $2.54 \mathrm{~b}$ \\
\hline Small & $2.53 \mathrm{a}$ & $2.28 \mathrm{a}$ & $2.86 \mathrm{a}$ & $0.93 \mathrm{c}$ \\
\hline $\operatorname{LSD}(0.05)$ & 0.193 & 0.305 & 0.323 & 0.554 \\
\hline \multicolumn{5}{|l|}{$\mathrm{pH}$} \\
\hline Control (distilled water) & $2.16 \mathrm{~b}$ & $1.70 \mathrm{c}$ & $2.28 \mathrm{c}$ & $3.27 \mathrm{ab}$ \\
\hline 4 & $2.41 \mathrm{a}$ & $2.27 \mathrm{ab}$ & $3.07 \mathrm{ab}$ & $2.23 \mathrm{~cd}$ \\
\hline 5 & $2.16 \mathrm{~b}$ & $1.91 \mathrm{bc}$ & $2.64 \mathrm{bc}$ & $2.44 \mathrm{bc}$ \\
\hline 6 & $2.08 \mathrm{~b}$ & $1.72 \mathrm{c}$ & $2.49 \mathrm{c}$ & $3.03 \mathrm{abc}$ \\
\hline 7 & $2.00 \mathrm{~b}$ & $1.63 \mathrm{c}$ & $2.25 \mathrm{c}$ & $3.71 \mathrm{a}$ \\
\hline 8 & $2.08 \mathrm{~b}$ & $1.85 \mathrm{bc}$ & $2.56 \mathrm{c}$ & $2.70 \mathrm{bc}$ \\
\hline 9 & $2.66 \mathrm{a}$ & $2.52 \mathrm{a}$ & $3.32 \mathrm{a}$ & $1.53 \mathrm{~d}$ \\
\hline $\operatorname{LSD}(0.05)$ & 0.295 & 0.467 & 0.494 & 0.847 \\
\hline
\end{tabular}

* The values followed by different letters are significantly different at $P<0.05$.

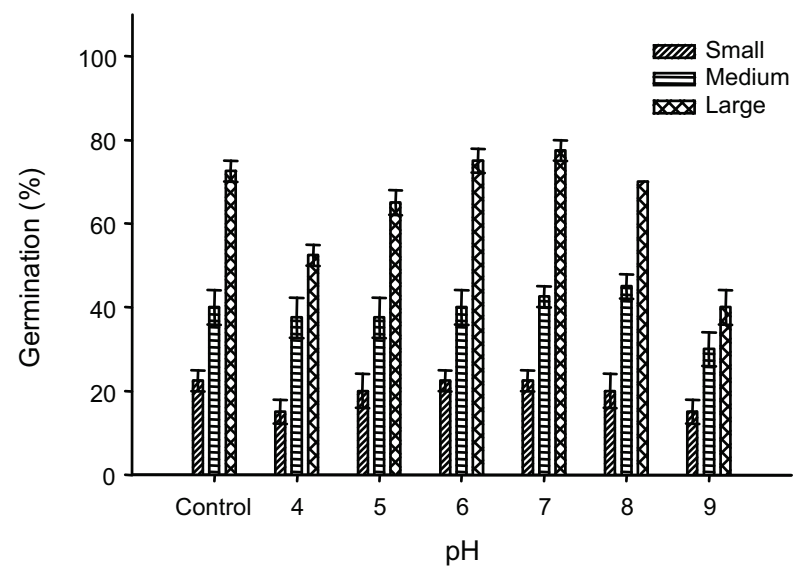

Figure 5 - Effect of seed size and $\mathrm{pH}$ on germination percentage of $C$. arvensis. Vertical bars represent \pm standard error of the mean.

was fitted to the emergence (\%) of three seed sizes of $C$. arvensis obtained at different seeding depths (Figure 2). Germination of C. arvensis seeds followed an exponential response to increasing seed size and seeding depth with decreased emergence as seeding depth increased from 0 to $8 \mathrm{~cm}$ and decreased in seed size from large to small (Figure 6). Emergence of small sized seeds was $20 \%$ in seeds placed on soil surface and steadily decreased with increasing seeding depth up to
$4 \mathrm{~cm}$. There was no emergence in small size seeds at 6 or $8 \mathrm{~cm}$ seeding depth (Figure 6). The model fitted to emergence of small seeds showed that emergence of $C$. arvensis decreased by $50 \%$ of the maximum germination at $2.7 \mathrm{~cm}$ seeding depth. Maximum emergence in medium size seeds was $71 \%$ in seeds placed at soil surface $(0 \mathrm{~cm}$ seeding depth) and decreased up to $2.5 \%$ at $6 \mathrm{~cm}$ seeding depth. The fitted model showed that medium size $C$. arvensis seeds had $50 \%$ emergence of the maximum emergence at $2.6 \mathrm{~cm}$ seeding depth (Figure 2). Large sized seeds had maximum emergence $(77.5 \%)$ when compared with small or medium sized seeds (Figure 2). The model fitted to large sized seeds showed that $50 \%$ of the maximum emergence occurred at $3.7 \mathrm{~cm}$ seeding depth (Figure 6). There was no emergence in medium and large sized $C$. arvensis seeds at $8 \mathrm{~cm}$ seeding depth.

Larger size seeds had high emergence index but low time to start emergence, time to $50 \%$ emergence and mean emergence time as compared to medium and small seeds (Table 6). Similarly, time to 50\% emergence and mean emergence time were 2.14 days and 2.81 days at surface seeding but these were 5.20 days and 5.52 days at $6 \mathrm{~cm}$ seeding depth (Table 6). Our findings are similar to those for 
Table 6 - Effect of seed size and seeding depth on different emergence parameters of C. arvensis

\begin{tabular}{|c|c|c|c|c|}
\hline Treatment & $\begin{array}{c}\text { Time to start } \\
\text { germination (days) }\end{array}$ & $\begin{array}{c}\text { Time to } 50 \% \\
\text { germination (days) }\end{array}$ & $\begin{array}{c}\text { Mean germination } \\
\text { time (days) }\end{array}$ & $\begin{array}{c}\text { Germination } \\
\text { index }\end{array}$ \\
\hline \multicolumn{5}{|l|}{ Seed size } \\
\hline Large & $2.90 \mathrm{a}^{*}$ & $2.80 \mathrm{ab}$ & $3.51 \mathrm{ab}$ & $3.00 \mathrm{a}$ \\
\hline Medium & $3.40 \mathrm{a}$ & $3.36 \mathrm{a}$ & $3.94 \mathrm{a}$ & $1.22 \mathrm{~b}$ \\
\hline Small & $1.90 \mathrm{~b}$ & $1.92 \mathrm{~b}$ & $2.68 \mathrm{~b}$ & $0.30 \mathrm{c}$ \\
\hline $\operatorname{LSD}(0.05)$ & 0.975 & 0.952 & 1.012 & 0.773 \\
\hline \multicolumn{5}{|l|}{ Seeding depth $(\mathrm{cm})$} \\
\hline 0 & $2.33 \mathrm{~b}$ & $2.14 \mathrm{c}$ & $2.81 \mathrm{~b}$ & $3.02 \mathrm{a}$ \\
\hline 2 & $2.91 \mathrm{~b}$ & $2.65 \mathrm{bc}$ & $3.43 \mathrm{~b}$ & $2.49 \mathrm{a}$ \\
\hline 4 & $3.41 \mathrm{~b}$ & $2.48 \mathrm{~b}$ & $5.12 \mathrm{a}$ & $1.92 \mathrm{a}$ \\
\hline 6 & $5.00 \mathrm{a}$ & $5.20 \mathrm{a}$ & $5.52 \mathrm{a}$ & $0.51 \mathrm{~b}$ \\
\hline 8 & $\mathrm{NG}$ & $\mathrm{NG}$ & NG & NG \\
\hline $\operatorname{LSD}(0.05)$ & 1.261 & 1.221 & 1.313 & 2.553 \\
\hline
\end{tabular}

* The values followed by different letters are significantly different at $\mathrm{P}<0.05 . \mathrm{NS}=$ Non significant and $\mathrm{NG}=\mathrm{No}$ Germination.

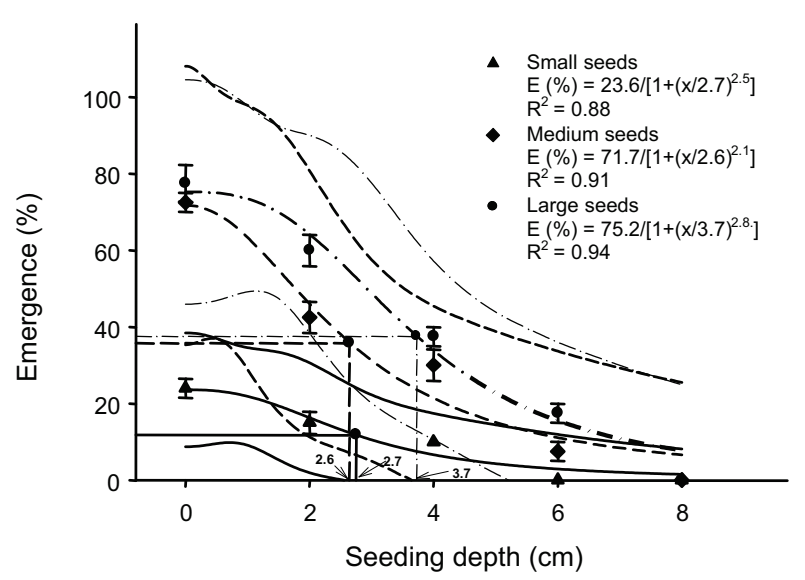

Figure 6 - Effect of seed size and seeding depth $(\mathrm{cm})$ on seed emergence of C. arvensis. Solid lines represent a threeparameter logistic model fitted to the emergence data of C. arvensis and thin lines show 95\% confidence interval. Continuous lines (-) represent small sized seeds, dash lines $(---)$ represent medium sized seeds and lines with a dot between dash $(-\cdot-\cdot-)$ represent large sized seeds. Vertical bars represent \pm standard error of the mean if greater than the symbol size.

pitted morning glory (Ipomoea lacunose), a member of the family Convolvulacae (Oliveira \& Norsworthy, 2006) but there was emergence at $10 \mathrm{~cm}$ seeding depth. Generally, seeds lying on or near the soil surface, as is common in no tillage system, germinate or emerge less than those in a tilled tillage system in large-seeded species (Bararpour \& Oliver, 1998). Field bindweed seeds took 2.33 days to emerge at surface sowing but at $6 \mathrm{~cm}$ seeding depth emergence occurred after 5 days. Seedling emergence of many weed species is adversely affected with increasing burial depth (Benvenuti et al., 2001; Benvenuti 2003; Chauhan \& Johnson, 2008a). Deep tillage operation that will bury seeds below $6 \mathrm{~cm}$ or deeper is a possible weed management option for farmers. However, larger seeds often have greater carbohydrate reserves and are able to emerge from greater depths of burial (Baskin \& Baskin, 1998). Harrison et al. (2007) depicted that giant ragweed seed size interacted with burial depth, affecting both the extent and timing of emergence and seed demise.

This study concludes that different ecological factors such as temperature, salinity, drought, field capacity, $\mathrm{pH}$ and sowing depth have an important role in germination of $C$. arvensis, which can possibly germinate/ emerge under varying ecological conditions. Larger seeds result in improved stand establishment and faster germination than small seeds, regardless of moisture stress, salt stress or deeper seeding depth. This study will be helpful in predicting suitable environments to germinate this weed, making it much easier to prevent it from spreading into new areas. 


\section{LITERATURE CITED}

ABOYAMI, Y. A.; ADEYINI, A. M. Comparative germination responses of cowpea and maize genotypes of soil moisture content. Agroresearch., v. 7, n. 20, p. 34-42, 2005.

ASSOCIATION OF OFFICIAL SEED ANALYSIS. Rules for testing seeds. J. Seed Sci. Technol., v. 12, n. 1, p. 1-112, 1990.

BARARPOUR, M. T.; OLIVER, L. R. Effect of tillage and interference on common cocklebur (Xanthium strumarium) and sicklepod (Senna obtusifolia) population, seed production and seed bank. Weed Sci., v. 46, n. 4, p. 424-431, 1998.

CHACHALIS, D. et al. Factors affecting seed germination and emergence of venice mallow (Hiviscus trionum).

Weed Sci., v. 56, n. 4, p. 509-515, 2008

CHACHALIS, D.; REDDY, K. N. Factors affecting Campsis rasicans seed germination and seedling emergence. Weed Sci. v. 48, n. 2 , p. $212-216,2000$

CHAUHAN, B. S.; JONHSON, D. E. Germination ecology of two troublesome asteraceae species of rainfed rice: siam weed (Chromolaena odorata) and coat buttons

(Tridax procumbens). Weed Sci., v. 56, n. 4, p. 567-573, 2008.

CHAUHAN, B.S. et al. Factors affecting seed germination of threehorn bedstraw (Galium tricornutum) in Australia. Weed Sci., v. 54, n. 3, p. 471-477, 2006.

COOLBEAR, P. et al. The effect of low temperature presowing treatment on the germination performance and membrane integrity of artificially aged tomato seeds. J. Exper. Bot., v. 35, n. 11, p. 1609-1617, 1984.

ELLIS, R. A.; ROBERTS, E. H. The quantification of aging and survival in orthodox seeds. Seed Sci. Technol., v. 9, n. 2, p. $373-409,1981$.

FORCELLA, F. et al. Modelling seedling emergence. Field Crops Res., v. 67, n. 2, p. 123-139, 2000.

GUBANOV, I. A. et al. An Illustrated identification book of the plants of Middle Russia, Vol. 3: Angiosperms (dicots: archichlamydeans). Moscow: Institute of Technological Researches, 2004. v. 3. p. 520.

HOLM, L. G. et al. The world's worst weeds: distribution and biology. Malabar: Krieer. The University Press of Hawaii, Honolulu, 1991. p. 98-104.

HORAK, M. J.; WAX, L. M. Germination and seeding development on bigroot morningglory (Ipomea pandurata). Weed Sci., v. 3, n. 3, p. 390-396, 1991
HUSSAIN, F. et al. Some autecological studies on Amaranthus viridis L. Pak. J. Weed Sci. Res., v. 9, n. 1/2, p. 117-124, 2003.

KHAJEH-HOSSEINI, M. et al. The interaction between salinity stress and seed vigour during germination of soybean seeds. Seed Sci. Technol., v. 31, n. 3, p. 715-725, 2003

KRITICOS, D. J. et al. Climate changes and potential distribution of an invasive alien plant: Accacia nelotica spp. Indica in Australis. J. Appl. Ecol., v. 40, n. 1, p. 111-124, 2003.

KOGER, C. H. et al. Factors affecting seed germination, seedling emergence and survival of texasweed (Caperonia palustris). Weed Sci., v. 52, n. 6, p. 989-995, 2004.

LAUBHAN, M. K.; SHAFFER, T. L. Seed germination of Cirsium arvense and Lepidium latifolium: implications for management of montane wetlands. Wetlands, v. 26, n. 1, p. $69-78,2006$

LEISHMAN, M. R. et al. The evolutionary ecology of seed size. In: FENNER, M. (Ed.). Seeds: the ecology of regeneration in plant communities. 2.ed. New York: $\mathrm{CAB}$ International. 2000. p. 31-58.

LYONS, K. E. Element stewardship abstract for Convolvulus arvensis L. In: Field bindweed. Arlington: The Nature Conservancy, 1998. p.1-21.

MEMON ASMA, R. Weed flora composition of wheat and cotton crops in District Khairpur, Sindh. $258 \mathrm{f}$. Thesis (Ph.D. in Botânica) - Shah Abdul Latif University, Pakstan, 2004.

MICHEL, B. E. Evaluation of the water potentials of solution of polyethylene glycol 8000 both in the presence and absences of other solutes. Plant Physiol., v. 72, n. 1, p. $66-70,1983$

MILLER, R. W.; DONAHUE, R. L. Soil water properties. In soils in our environment, Upper Seddle River, New Jersey: Prentice Hall, 2004. p. 62-97.

OLIVEIRA, M. J.; NORSWORTHY, J. K. Pitted morningglory (Ipomoea lacunosa) germination and emergence as affected by environmental factors and seedling depth.

Weed Sci., v. 54, n. 5, p. 910-916, 2006.

$\mathrm{RAO}, \mathrm{N}$. et al. Influence of environmental factors on seed germination and seedling emergence of american sloughgrass (Bechmannia syzigachne). Weed Sci., v. 56, n. 4, p. 529-533, 2008.

STATISTICALANALYSIS SYSTEMS - SAS. SAS procedures guide. Version 9.Cary: Statistical Analysis Systems Institute, 2002. 
SMITH, P. T.; COMB, B. G. Physiological and enzymatic activity of pepper seeds (Capsicum annиum) during priming. Physiol Plant., v. 82, n. 3, p. 71-78, 1991.

STEEL, R. G. D. et al. Principles and procedures of statistics. 3.ed. New York: McGraw Bill Book, p. 178-198. 1997.

SUSKO, D. J. et al. Influence of environmental factors on germination and emergence of Pueraria lobata. Weed Sci., v. 47, n. 5 , p. $585-588,1999$

THOMAS, W. et al. Influence of environmental factors on slender amaranth (Amaranthus viridis) germination.

Weed Sci., v. 54, n. 2, p. 316-320, 2006.

WANG, J. et al. Factors affecting seed germination of cadillo (Urena lobata). Weed Sci., v. 57, n. 1, p. 31-35, 2009.
WATANABE, H. et al. Environmental factors affecting germination of apple of Peru. Weed Sci., v. 50, n. 2, p. 152-156, 2002.

WILLENBORG, C. J. et al. Oat germination characteristics differ among genotypes, seed sizes and osmotic potentials. Crop Sci., v. 45, n. 5, p. 2023-2029, 2005.

KOYRO, H. W.; EISA S. S. Effect of salinity on composition, viability and germination of seeds of Chenopodium quinoa Willd. Plant and Soil, v. 302, n. 1, p. 79-90, 2008.

ZHOU, J. et al. Factors affecting germination of hairy nightshade (Solanum sarrachoides) seed. Weed Sci., v. 53, n. 1, p. $41-45,2005$ 